\title{
The politics of GCSE English Language
}

\author{
BABETTE VERHOEVEN
}

University of Huddersfield

\section{Popular language ideology's influence on England's National Curriculum English Language qualification}

\section{Introduction}

In 2015, England saw the introduction of a new GCSE English Language ${ }^{1}$, as part of changes to the National Curriculum (NC). ${ }^{2}$ At the time, concerns about and protests against the proposed new GCSE English Literature were widely reported (Kennedy, 2014; Tickle, 2013), while the proposed new GCSE English Language attracted less popular attention and criticism. However, GCSE Results Day on the $22^{\text {nd }}$ of August 2019 saw criticism about English Language taking centre stage (Andrews, 2019; Leedham, 2019). The main concerns are that:

1. the exams for GCSE English Language are too difficult for a significant number of students, without any real alternative English qualification on offer;

2. students aged 16-193 who fail to achieve at least a Grade 4 (pass) are required to re-take their GCSE English Language;

3. the repetitive, narrow focus of the GCSE English Language course itself means that significantly fewer students are taking up English Language at A level (Leedham, 2019; Whittaker, 2019).

This recent concern about the current GCSE English Language can be regarded as an iteration of long-standing concerns about the teaching of secondary English: the lack of a clear definition of English as a school subject ${ }^{4}$ and the issue of many secondary English teachers lacking the relevant expertise in English language or linguistics (Hudson, 2019). However, this paper will argue that popular language ideologies current in
England are also an important contributing factor in the shaping of both the NC for English and its associated final examination, the GCSE English Language qualification.

\section{Some context: A brief history of GCSE English and the English NC}

In 1988, the NC for England was introduced: it prescribed what should be taught for every subject. The introduction of such a curriculum for the school subject L1 English was certainly challenging if not

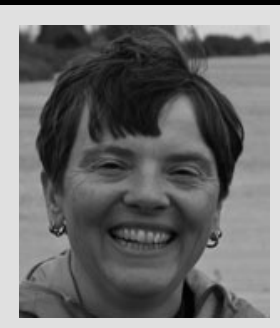

BABETTE VERHOEVEN obtained her MA in English Language and Literature from the University of Amsterdam, where she also completed initial teacher training. She qualified as an English teacher in England in 2003 and has taught in secondary schools, $6^{\text {th }}$ form and Further Education colleges. Currently, she teaches A level English Language and re-sit GCSE English Language in a $6^{\text {th }}$ form college in Cheshire. She also has extensive experience of examining both GCSE and A level English Language and at present is an A level English Language Principal Examiner. In her spare time, she writes Linguistics Olympiad puzzles and is studying for a PhD in Linguistics at the University of Huddersfield. Her research focuses on developing corpus linguistics methods for extracting language ideologies, as well as exploring the impact of language ideologies on secondary English teachers.

English Today 151, Vol. 38, No. 4 (December 2022). Printed in the United Kingdom Cambridge University Press This is an Open Access article, distributed under the terms of the Creative Commons Attribution 
contentious (Cameron, 1995); this is evident in the publication of three government reports on English alone. There was the original report commissioned by the Labour government for the introduction of the NC, A Language for Life (Bullock et al., 1975), which was followed by two reports commissioned by the Conservative government a decade later, The Kingman Report (1988) and the Cox Report (1989). Following the recommendations of these various reports, the Language in the National Curriculum (LINC) project was established in order, in the words of its chair:

to assist teachers with materials in preparation for the delivery of a National Curriculum and [as such it] was designed with a recognition that most teachers at that time did not receive formal training in or had only minimal background in the description of the English language. (Carter, 2007: n.p.)

After a review in 1991, 'the government decided against publication but allowed the materials to be distributed in samizdat form for purposes of continuing training' (Carter, 2007: n.p.). The controversies surrounding this decision have been well documented (Cameron, 1995; Carter, 1996) and are indicative of the ways in which government attitudes can affect the definition of L1 English.

The 1997 election of a Labour government brought changes for the teaching of English: the National Literacy Strategy (NLS) (1998) and the rolling out of the Framework for Secondary English. As a result, the English curriculum became a more narrowly dogmatic one ${ }^{5}$, which approached the subject of English partly as a functional (and mechanical) language skill, partly as the repository of the nation's cultural heritage in the form of English Literature, and partly as a means of inculcating progressive values. In other words, a government's beliefs about the nature of English and its teaching shaped what happened in English classrooms across the country without much consultation of appropriate experts, such as linguists; an established pattern in reforms of English teaching.

The Conservative-Liberal Democrat coalition government in 2010 initiated a review of the NC, which resulted in the introduction of the current, revised English curriculum. There was some consultation of English Language and Linguistics experts, but only for much of the advice to be ignored or dismissed by the Department of Education (DfE) ${ }^{6}$; a repeat of 1991's LINC project. This is one of the reasons why there is no connection between Primary's KS2 English with its focus on language analysis and Secondary's KS3 English, which lacks such a focus. As a result, Year 6 pupils are expected to identify word classes and comment on a writer's use of fronted adverbials, but there is then no follow-up in Years 7 to 9 English at all, resulting in loss of skills and understanding. When pupils start Year 10 and preparations for GCSE English commence, language analysis is rather limited and ill-defined so that it is not taught consistently. That is to say, when it is taught at all, since most of the English teaching in Years 10 and 11 in the runup to GCSEs focuses on English Literature, rather than English Language (Leedham, 2019). This limits the time and resources spent on English Language overall, but especially the teaching of language analysis since this is the topic most English teachers feel insecure and dismissive about (Davies, 1992; Giovanelli, 2015; Watson, 2012).

\subsection{Language ideology and the English curriculum}

It is understandable that since governments of any political persuasion hold strong beliefs about education (as indeed about many other social issues), this will affect how they legislate for and proceed to influence relevant policy areas. With regard to the teaching of secondary L1 English in England, this is most notable in the promotion of literary studies over language analysis. A possible explanation why so much English teaching is concerned with teaching literature is the longstanding issue with English teachers lacking specific linguistic subject knowledge (Carter, 2007; Giovanelli, 2015; Hudson, 2019; Watson, 2012). Nevertheless, it is also possible to detect government policy influences in this privileging of literature; a practice which dates back to the Newbolt Report (1921) and before (Mathieson, 1975). Similar, obviously political ideological influences on the English curriculum have not gone unnoticed and elicit much of the criticism of the construction of English curricula (Lough, 2019; Protherough \& Atkinson, 1991; Tickle, 2013).

However, when it comes to L1 English teaching, there is another issue that affects government's legislation on language education, namely language ideology. A concept from linguistic anthropology, 'language ideology' refers to a 'ubiquitous set of diverse beliefs, however implicit or explicit they may be, used by speakers of all types as models for constructing linguistic evaluations and engaging in communicative activity' (Kroskrity, 2004: 497). Clearly, linguists' beliefs about language are also examples of language ideology, 
but as linguists make up only a small number of English speakers, popular beliefs about language in the UK mostly take the opposite of a linguistically informed ideological stance (Bauer \& Trudgill, 1998). Examples of such popular language ideologies current in England are the beliefs that:

- some regional and social varieties of English are 'incorrect forms of English' e.g. nonstandard dialectal forms such as 'we was';

- there is an easily identifiable variety of English that experts and educators alike can all agree on is standard English;

- youth sociolects are ungrammatical and thus 'incorrect English', which is affecting the English language to its detriment;

- English is currently in decline since so many of its native speakers do not use it 'properly';

- schools should teach children to speak and write 'correct English' (which is equated with standard English); and so on (Cameron, 1995; Verhoeven, 2019).

While ideologies that are overtly political have been critiqued for their impact on the construction of the secondary English curriculum (Helm, 2019; Kennedy, 2014; Lough, 2019; Protherough \& Atkinson, 1991), popular language ideology often goes under the radar, since it consists of widely held, 'common sense' ideas about language and its usage. This means that popular language ideology's effect on the English curriculum goes unnoticed, since, when an English curriculum is constructed or updated, linguists are not invited to contribute or their expert advice is disregarded and ignored (see section 2 above).

This lack of English language/linguistics expertise explains why current secondary English NC documents, as well as English language subject guidelines from $\mathrm{Ofqual}^{7}$, and the approved exam board specifications for GCSE and A level English Language provide a confusing approach to the teaching of English language. These documents insist on both a traditional and popular prescriptivist, as well as a more linguistically informed (in the spirit of the jettisoned LINC project) descriptivist language ideological approach to L1 English. This results in contradictions (Cameron, 1995: 102) that are hard for English teachers lacking linguistic training to reconcile and are a likely contributing factor to the longstanding problem of English language teaching in England (Verhoeven, 2017).

In practice this means that secondary English teachers are exhorted to celebrate the diversity of English, such as the nonstandard regional dialectal features of their students, while at the same time penalising any student who uses a nonstandard English variety in written or spoken work. Bizarrely, neither NC documentation nor exam board specifications provide an actual definition of standard English ${ }^{8}$; the popular language ideological assumption is that the teacher will know it when they see it. Thus, it is not surprising that English teachers who are already unsure about language or linguistic topics are made more insecure in their subject knowledge and subsequent ability to teach the subject.

\subsection{Current Key Stage 4 English teaching and popular language ideological influences}

While the language ideological issues outlined in Section 3.1 affect both A level and GCSE English Language teaching, their potential impact is more strongly felt in the teaching of the latter, as most A level English Language teachers are likely to have had training in English language/linguistics, unlike the majority of their colleagues who only teach English Language up to GCSE. The four current, Ofqual-approved GCSE English Language specifications ${ }^{9}$ were among the first of the new, more challenging, GCSEs with the numerical grades 1 to 9 to be taught following the $\mathrm{NC}$ reforms. Since English Language is one of the subjects at GCSE that is measured in Progress 8 and counts towards the Ebacc $^{10}$, it is effectively compulsory for all KS4 pupils, which means that almost all English teachers in England will be teaching this qualification in a given school year.

As students cannot be entered for a combined Language and Literature GCSE ${ }^{11}$ and since schools timetable for English as one subject, it is during these timetabled lessons that both GCSE English Literature and GCSE English Language have to be taught. As Leedham (2019) argues, this results in the privileging of literature over language, partly because of the perception that there is more English Literature content to cover. However, there is also the opinion that language will take care of itself in the English classroom, as reading literary fiction and non-fiction texts will result in the implicit transfer of reading skills to writing skills. This fairly common assumption exists among English teachers (and DfE staff responsible for the English curriculum) even though research suggests this is a fallacy and explicit teaching of writing based on language analysis is more effective (Myhill, 2016).

The misperception of how writing skills are acquired in L1 English is partially the result of popular language ideology. The English teachers, 
Ofqual staff, DfE staff and ministers, who hold these beliefs, maintain that by studying literary texts, students are exposed to proper English. Many of the prescribed text choices for GCSE English Literature are traditional English cannon classics (e.g. a Shakespeare play, a $19^{\text {th }}$-century novel), which in their language are far removed from any contemporary socio- and ethnolects or regional dialects used by GCSE students themselves. As such, analysis of these texts, so it is wrongly assumed, will teach the students the appropriate use of standard English and formal registers to allow for a bi-dialectal existence (in the less prescriptive classroom) or an abandoning of nonstandard forms in favour of the standard (in the more prescriptive classroom).

Of course, a focus on literary texts does not automatically have to entail a rejection of language analysis. Literary texts can be approached and analysed in a linguistic manner, however, what passes for textual analysis in many KS4 English lessons is literary analysis, rather than linguistic analysis. This conflation of literary analysis with language analysis again points to the popular language ideological issue at stake here: the belief that canonical literary texts are a repository of good (standard) English, which can be acquired by mere exposure to it. This is because another popular language ideology makes itself felt, too, namely the belief that native speakers of English have all the requisite knowledge and require no formal teaching of their language. This particular ideology contradicts the simultaneously held belief that English is being damaged by the abuse heaped on it by native speakers; however, part of the latter belief is that the abusive native speakers are doing so because they are lazy and cannot be bothered (Cameron, 1995). In other words, the natives choose to abuse the language, despite the fact that they know and could do better (Verhoeven, 2019).

\subsection{Literature on the GCSE English Language syllabus: an unexpected popular language ideological effect}

While Section 3.2 identified some ways in which popular language ideology is making itself felt in the teaching of KS4 English, it is when GCSE English Language as a separate course is considered that such language ideological influences become even more pronounced. While there are four different GCSE English Language specifications schools and colleges can choose from, about half of all the entries for GCSE English Language are with AQA: approximately 500,000 students sit AQA's GCSE English Language exams (AQA, 2019). Therefore, in the discussion that follows, specific examples are taken from AQA's 8700 English Language qualification. Since Ofqual sets out the guidelines for exam boards, all four GCSE English Language specifications have the same nine Assessment Objectives (AOs) for their written examinations and spoken language non-exam-assessed components. So the discussion below applies to all four GCSE English Language syllabuses generally, even though the specifics will differ.

Surprisingly, the privileging of literature as discussed in Section 3.2 not only makes itself felt in the general teaching of KS4 English, but also exerts its influence on the GCSE English Language syllabus and its AOs. Despite the title, GCSE English Language involves the study of literature $^{12}$ : depending on which exam board is chosen, students will have to tackle questions on either one or more literary fiction extracts. And even the remaining non-fiction text or texts tend to be literary in style. Hence, students are to be credited when they apply methods of literary analysis in their responses to questions on the GCSE English Language exam papers. Of the relevant AOs, $\mathrm{AO} 2$ specifies only 'relevant subject terminology' (AQA, 2016: 16), which covers both linguistic and literary terminology, while $\mathrm{AO} 3$ clearly privileges literary analysis: 'Compare writers' ideas and perspectives, as well as how these are conveyed' (AQA, 2016: 16). Of course, the notion of conveying writers' ideas could potentially suggest linguistic analysis, but it is frequently interpreted as promoting literary analysis. A similar argument applies to AO4's 'evaluate texts critically' (AQA, 2016: 16), which is more likely to invite literary than linguistic analysis. Furthermore, the nonspecified nature of the analysis encourages conflating the two approaches.

Also, since the belief that reading good quality literary texts will lead to students becoming proficient at good English usage is underpinning the whole syllabus, it is not surprising to see that the exams' writing questions expect literary writing from students. On AQA's first exam paper, students are expected to either produce a piece of descriptive writing (which often has narrative elements) or a piece of fiction: evidence of the popular language ideologically influenced promotion of literary texts over more real-life, practical texts, as usually advocated by educational linguists (Carter, 1990). ${ }^{13}$ AQA's second paper's writing task is arguably more relevant for developing such practical writing skills, with its focus on 
writing to argue or persuade. However, the genres that students are expected to be able to produce include newspaper articles, speeches, or formal letters. Of these, only the letter is an example of a text that would be helpful for secondary school leavers to be able to produce, whereas the others display once more a privileging of literary text genres and styles.

The notion that English should provide practical applications is of course also language ideological. The idea that school leavers should be equipped with the literacy skills they need has always been part of the NC and indeed, current GCSE exam specifications emphasize this aspect, too:

The specification will enable students of all abilities to develop the skills they need to read, understand and analyse a wide range of different texts covering the $19^{\text {th }}, 20^{\text {th }}$ and $21^{\text {st }}$ century time periods as well as to write clearly, coherently and accurately using a range of vocabulary and sentence structures (AQA, 2016: 5).

The discussion so far, just as with AQA's GCSE specification, has focused on the outcomes, but it is important to consider the processes of literacy, especially with regard to writing. Because there is no longer any non-exam-assessed coursework or controlled assessment, students are asked to write a newspaper article on the spot, which is very much removed from the reality of such writing, as drafting, re-writing, and editing are a part of the writing process. While GCSE English teachers will encourage their students to plan and proofread, under the time constraints of exam conditions these actions will be nothing like the drafting process involved in such writing. And while this issue is perhaps more the result of moving to an examinations-only qualification, it is possible to detect popular language ideological influences in the assumption that students will be able to write a completed piece, since they will have been exposed to similar examples of non-fiction prose reading and writing.

\subsection{Popular language ideological issues in current GCSE English Language assessment criteria}

In the assessment criteria, (AOs), popular language ideological influences are immediately apparent, most notably in the final one, $\mathrm{AO}$, which applies only to the spoken language assessment. AO9 makes it clear that in their speeches and presentations, students must use 'spoken standard English effectively' (AQA, 2016: 17). One popular language ideological notion here is that any educated person will be able to identify what standard English is, but more surprisingly from a linguistic viewpoint is the idea that there is spoken standard English. Does this mean that English teachers in England's North West cannot award a pass to their students for the spoken language assessment if the latter employ northern English lexical choices e.g. 'ginnel' instead of 'alley'; or northern English grammar e.g. the common dialectal form of copular 'to be' with past participles 'stood' or 'sat', as in 'I was stood' instead of the standard English form of auxiliary 'to be' with present participles 'standing' or 'sitting' as in 'I was standing'?

As the spoken language assessment does not contribute towards the final GCSE English Language grade, it is merely 'separately endorsed' (AQA, 2016: 15), English teachers and their students probably pay minimal attention to it and its AOs. Yet, there are similar issues with AO1 to AO6, which are the assessment criteria for the written examinations. AO5 and AO6 are the assessment criteria for the written tasks, where AO5 insists students use 'structural and grammatical features to support coherence and cohesion of texts' (AQA, 2016: 16). This implies that students' written work must make sense to be awarded marks. Uncontroversial perhaps, but how many English teachers and examiners would consider only grammatical features such as subject-verb agreement or tense management and overlook lexical and discourse cohesion? Furthermore, there is the ambiguity of 'structural features', since this term in the relevant reading criterium (AO2) is strictly literary, covering such narrative concepts as flashback, point of view, and narration. Therefore, it is likely that structure in AO5 will also be understood primarily in this literary interpretation, thus promoting the teaching of stylistic devices over teaching understanding of language structures in the sense of phrases, clauses, or whole text discourse.

Also, when considering making sense in writing from a popular language ideological point of view, standard English is considered essential and is often reduced to its most visible or recognisable features: spelling, punctuation, and grammar (in the prescriptivist sense). Indeed, the second assessment objective for writing at GCSE, AO6, states students must use 'a range of vocabulary and sentence structures for clarity, purpose and effect, with accurate spelling and punctuation' (AQA, 2016: 16), which suggests that employing varied vocabulary is of a similar level of importance and difficulty as spelling or punctuation. While this is not necessarily how this $\mathrm{AO}$ is interpreted by examiners, nevertheless it is what is implied at first glance, without any further clarification such as that received in examiner 
training. Teachers, unless they become examiners or attend follow-up professional development training, do not have this insight and can only take the $\mathrm{AO}$ at face value. This narrow focus on certain aspects of English language usage, possibly to the detriment of other linguistically more interesting or complex aspects, again evokes widely held language ideological beliefs that reduce good English to features that are easy to spot and are often fetishized in popular prescriptive English usage books such as Humphrys (2006) and Truss (2003).

Incidentally, the insistence on students using a wide variety in their vocabulary and sentences leads to teaching to the test, such as students being trained to use low-frequency adjectives and to start at least one sentence with a present participle and another with an adverb. ${ }^{14}$ It also reinforces the familiar, pernicious idea that good writing is inherently literary. While this is a very narrow interpretation of what makes a text literary, it implies that variety and complexity for the sake of variety and complexity are what makes for good English. Finally, it promotes a formulaic approach to writing without any actual understanding of the nature of written English, thus stymieing the development of literacy.

\subsection{Popular language ideology and the unsuitability of GCSE English Language as a qualification}

Both Sections 3.3 and 3.4 above conclude that the current GCSE English Language qualification is not developing school leavers' general literacy skills. This is a serious concern and one that has been central in the criticisms of this GCSE English Language (Nutt, 2019; Whittaker, 2019). It is also not a new problem and owes much to the construction of L1 English as an examined school subject (Pearce, 1974; Protherough \& Atkinson, 1991). The previous GCSE English Language specifications, while still subject to similar popular language ideological concerns such as the privileging of literature over linguistic analysis, featured questions where students were asked to identify facts and opinions in newspaper articles: critical reading skills essential in the age of social media and fake news (Nutt, 2019). The current GCSE English Language, despite the insistence to the contrary in exam board specifications, offers little in terms of literacy skills development and in some exam questions, it may even be counterproductive.

For example, AQA's paper 2, which features two non-fiction texts on similar topics $\left(\mathrm{a} 19^{\text {th }}\right.$-century one and the other $20^{\text {th }}$ - or $21^{\text {st }}$-century) asks students to write a summary of the two texts, focusing on their differences, similarities, or both. Summarizing is a key skill, beneficial for further study as well as employment and indeed life in the $21^{\text {st }}$ century. The relevant assessment objective, $\mathrm{AO} 3$, asks students to 'compare writers' ideas and perspectives' (AQA, 2016: 16), which suggests developing critical reading skills as in the ability to distinguish between fact and opinion or the ability to infer meanings. However, students are expected to support their summary with quotations from the two texts, which should support 'detailed synthesis' (AQA, 2018b: 8). The insistence on quotations as evidence undermines the idea that students are writing a genuine summary, as for much of their answer students are expected to explore differences and/or similarities based on literary analysis of the texts by means of the quotations. Thus, students are writing a comparison of two texts, which is labelled a summary. So, it is no wonder that when GCSE students proceed to A level study, Further Education, or employment, they may struggle, when asked, to summarize.

Furthermore, in this particular exam, students are applying their skills and understanding to texts from different periods without reference to the fact that the English language over the intervening 200 to 150 years has changed. There is no reference in the assessment objectives or specifications to language change, so it is not taught. While studying language change may not be relevant at the level of GCSE, the fact that a contemporary text can be presented alongside one that is 200 years older without any reference to language change suggests the popular language ideological myth of language as unchanging (Bauer \& Trudgill, 1998). This is especially interesting when one considers the notion underpinning so much of the secondary L1 English curriculum, namely the exposure to good English texts resulting in good writing proficiency. This begs the question: does the DfE intend for all $21^{\text {st }}$-century young people to write like a minority of $19^{\text {th }}$-century people?

And question 2 on AQA paper 2 is not alone; there are similar issues with other questions on both exams, where the phrasing of the question itself is quite misleading. For example, on paper 1, question 3 always employs the same phrasing: 'how has the writer structured the extract to interest you as a reader?' (AQA, 2018a: 6). This is problematic with re-sit students, who do not tend to think of themselves as readers and are inclined to answer: 'I am not interested as a reader'. Similarly, question 4 on the same paper, invites 
students to give their opinion on the fiction extract after prompting with an evaluative statement. It is implied that students agree with the statement in order to answer the question correctly. This makes the notion of the students evaluating the extract problematic, since they are not necessarily giving their own opinions.

As a result of these confusing questions, GCSE re-sit students especially are likely to learn that formal and official forms of English (such as that in exam questions) cannot be taken at face value; that language exists to befuddle and catch them out. This reinforces the perception for many students from poorer socio-economic backgrounds in the regions beyond England's South-East, that standard English is not their language, but the language professionals such as teachers and exam boards use to show them up. Unacknowledged here is the issue that popular language ideological beliefs such as that in the nature of standard English as the better variety of English are often rooted in social and class prejudice (Anderson \& Trudgill, 1990; Bauer \& Trudgill, 1998; Cameron, 1995). Worse still, not only does this confirm a pernicious language myth, but it actively reinforces it.

\subsection{GSCE English Language and A level English Language}

While for most students, GCSE English Language will be the last qualification they take in English Language, some will continue to A level English Language. From its introduction as an A level subject in the 1980s, English Language has been a popular choice, but a noticeable downward trend occurred when the new GCSE English Language was introduced (Hughes, 2019; Leedham, 2019). Since the new GCSE English Language's introduction in 2017, the number of candidates entered for A level English Language has fallen by approximately one third (FFT Education datalab, 2019). This is problematic, as this trend will affect university study of English language, which could ultimately result in even fewer English Language qualified teachers of English.

Since the subjects at GCSE and A level have the same name, 'English Language', most students assume that the A level course will be a continuation of their GCSE studies. This is probably one reason that currently students are not taking up A level English Language (Hughes, 2019; Leedham, 2019). However, for students who do continue with English Language at A level, there is a surprise, as they realise that the A level course they have chosen has little in common with the
GCSE course of the same name. This is because A level syllabuses are partly if not mostly constructed by subject experts. Since A levels are the typical university entrance qualifications, universities are able to influence A level English Language specifications (AQA, 2012); this is not the case with GCSE specifications. While there are still some popular language ideological influences present in A level English Language specifications (Verhoeven, 2017), their effects are mitigated as students are taught a descriptivist, scientific approach to language study at A level; the result of linguistically informed language ideology. Instead, a more serious problem is that new A level English Language students have to be trained out of bad GCSE English Language habits. Since linguistic analysis has been consistently conflated with literary analysis at GCSE, students have to be encouraged to re-learn what is meant by textual analysis. This becomes a bigger problem when students are confronted with this in an English Language classroom where they are supposedly studying the subject that they thought they knew. The resulting experience of cognitive dissonance initially affects many students' performance, since they have to work through this disconcerting experience, before they can engage fully with learning. ${ }^{15}$

\section{Conclusion}

The current GCSE English Language qualification does not prepare students suitably for life after school, as it does not equip them with the necessary literacy skills. Indeed, the disregard for developing literacy is one of the most serious criticisms aimed at the current GCSE English Language qualification (Nutt, 2019; Whittaker, 2019). The unacknowledged popular language ideology underpinning the construction of the English curriculum provides an answer as why this disregard for literacy instruction is virtually at the heart of England's only compulsory secondary school L1 English qualification. The commonly held language ideological conviction that by exposing native English speakers to good quality literary text types they will become literate means that those in charge of constructing the curriculum and its related GCSE specifications do not think to include explicit instruction in reading and writing.

As a result of these popular language ideological effects, the current GCSE English Language qualification does not equip students with the literacy skills required for navigating life in the $21^{\text {st }}$ century. Nor does it prepare students for the study of 
English Language at A level. In fact, for many students who do choose to study A level English Language, their experience and knowledge from GCSE English Language is often a hindrance. That is, of course, if they have not already been thoroughly disenchanted with the subject of English Language by the time they are deciding on their A level courses.

Finally, the current GCSE English Language does nothing for the teachers without English language or linguistics training, who are mostly finding their own, pre-existing language ideology, rooted in common sense language myths, confirmed. As most English teachers lack such English language or linguistics training, an issue that is not tackled in teacher training and professional development, this is an opportunity missed. If England were to have a GCSE English Language (and with it, a NC) rooted in linguistic knowledge and language study (Van Rijt \& Coppen, 2017), it would be more likely to provide the students with the appropriate skills and knowledge, while ensuring that their teachers would be, too.

\section{Notes}

1 General Certificate of Secondary Education: compulsory exams taken at 16 in England, Northern Ireland and Wales, first introduced alongside the NC in 1988. 2 The NC consists of 4 Key Stages: KS1 (age 4-7) and KS2 (7-11) cover Primary Education, while KS3 (11-14) and KS4 (14-16) cover Secondary Education. KS4 equates with GCSE, which tends to be taught over the two years of KS4.

3 Students are expected to re-take English Language between 16 and 19 (and up to aged 25, if still in education and in possession of an Educational Health Care Plan).

4 Such as: should English be literature, language, literacy, or a combination of these? (Pearce, 1974). There is also the tendency for other topics being put on the English curriculum: e.g. personal development, learning about different cultures etc. (Doecke, Homer \& Nixon, 2003).

5 The author's copy of the Key Stage 3 National Strategy (DfEE, 2001) suggests a linear progression during which students master different reading, writing and speaking skills in a strict order, such as spelling of challenging words before paragraphing, for example.

6 Researchers in the relevant fields, from the Linguistics Association of Great Britain (LAGB) and the Committee for Linguistics in Education (CLiE) were consulted. As with the LINC project, the experts made suggestions and provided materials, only for the Government to decide not to use the materials intended for KS3 and KS4 English, but publish them as a separate glossary and appendices. (Personal communication, 27 February 2018).
7 Office of Qualifications and Examinations Regulation, a non-government body, administers all aspects of the examinations system in England.

8 Only the KS3-KS4 glossary of linguistic terminology includes an accessible explanation of standard English and provides some typical nonstandard examples. This glossary is easily overlooked, since it is a separate document and not included with the NC English documents. English teachers working in sixth form and FE colleges will not be aware of the glossary's existence, since they do not follow the NC.

9 These are specifications offered by: AQA, Edexcel, Eduqas (WJEC), and OCR.

10 Progress 8 is an accountability measure for statefunded schools in England (DfE, 2019), where students' test results in eight subjects, including English Language, are measured at the end of their primary and secondary education in order to be compared. The English Baccalaureate consists of GCSEs in English Language, English Literature, Maths, Sciences, Geography or History, and a language. Secondary schools are judged on their Progress 8 results, but also on how many students achieve an EBacc.

11 Such a qualification does not exist at GCSE, but does at A level.

12 This has been the case with previous GCSE English Language qualifications. The current GCSE English Language no longer includes the study of poetry and a Shakespeare play, because with Progress 8 , it is no longer possible for schools to only enter students for GCSE English Language. The previous English Language GCSE deliberately included Shakespeare and poetry to prevent students (not entered for GCSE English Literature) from not having to study these canonical literary texts.

13 This may also be a left over from the long-standing belief about secondary English as the subject that promotes creativity and literature as a means to protect children against the mechanization of society (Mathieson, 1975).

14 The author has come across this as a GCSE English teacher.

15 In the author's experience as a teacher of A level English Language, more students switch to different A level courses from English Language than they do from English Literature or English Language \& Literature. Many cite the fact that the English Language course is not what they expected as the reason for changing. Among the students who stay the course, there is often resistance to A level material where this goes against what has been taught on the GCSE course.

\section{References}

Anderson, L.-G. \& Trudgill, P. 1990. Bad Language. London, UK: Penguin Books.

Andrews, J. 2019. 'GCSE reforms failed to improve A level results in English and Maths'. The Guardian, August 15. 
Online at: <https://www.theguardian.com/education/2019/ aug/15/gcse-reforms-failed-to-improve-a-level-results-inenglish-and-maths $>$ (Accessed November 3, 2019).

AQA. 2012. 'Developing new AS and A levels English' [Conference]. October, 26. Sheffield, UK: University of Sheffield.

AQA. 2016. GCSE ENGLISH LANGUAGE (8700)

Specification. Online at: <http://www.aqa.org.uk/subjects/ english/gcse/english-language-8700> (Accessed November 3, 2019).

AQA. 2018a. 'GCSE ENGLISH LANGUAGE Paper 1 Explorations in creative reading and writing' [exam paper]. November 5. Online at: $<$ https://filestore.aqa.org. uk/sample-papers-and-mark-schemes/2018/november/ AQA-87001-QP-NOV18.PDF> (Accessed November 3, 2019).

AQA. 2018b. 'GCSE ENGLISH LANGUAGE Mark scheme Paper 2 November 2018.' Online at: <https:// filestore.aqa.org.uk/sample-papers-and-mark-schemes/ 2018/november/AQA-87002-W-MS-NOV18.PDF> (Accessed February 14, 2020).

AQA. 2019. 'AQA in Numbers 1 April 2018 to 31 March 2019.' Online at: $<$ https://www.aqa.org.uk/about-us/whowe-are/aqa-in-numbers $>$ (Accessed November 3, 2019).

Bauer, L. \& Trudgill, P. (eds.) 1998. Language Myths. London, UK: Penguin Books.

Bullock, A. et al. 1975. A Language for Life. Report of the Committee of Enquiry appointed by the Secretary of State for Education and Science under the Chairmanship of Sir Alan Bullock FBA. London, UK: HM Stationery Office. Online at: <http://www.educationengland.org.uk/ documents/bullock/> (Accessed November 3, 2019).

Cameron, D. 1995. Verbal Hygiene. London, UK \& New York, USA: Routledge.

Carter, R. (ed). 1990. Knowledge about Language and the Curriculum. The LINC Reader. London, UK: Hodder and Stoughton.

Carter, R. 1996. 'Politics and knowledge about language: The LINC project.' In R. Hasan \& G. Williams (eds.), Literacy and Society. London, UK: Longman, pp. 1-21.

Carter, R. 2007. 'Introduction to LINC materials.' Online at: $<$ https://clie.org.uk/linc/> (Accessed November 3, 2019).

Cox, B. et al. 1989. The Cox Report: English for Ages 5 to 16. London, UK: HM Stationery Office. Online at: $<$ http:// www.educationengland.org.uk/documents/cox1989/> (Accessed November 3, 2019).

Davies, C. 1992. 'English teachers' ideologies: An empirical study.' British Educational Research Journal, 18(2), 193207.

DfEE. 2001. Key Stage 3 National Strategy. Framework for Teaching English: Years 7, 8, and 9. London, UK: Department for Education \& Employment.

DfE. 2019. Secondary Accountability Measures. Guide for Maintained Secondary Schools, Academies and Free Schools. Online at: <https://www.gov.uk/government/ publications/progress-8-school-performance-measure> (Accessed November 3, 2019).

Doecke, B., Homer, D. \& Nixon, H. (eds.) 2003. English Teachers at Work. Narratives, Counter Narratives and Arguments. Australian Association for the Teaching of English Interface Series. Kent Town, South Africa: Wakefield Press.
FFT Education datalab. 2019. 'Results day analysis: English Language A level.' Online at: <https://results. ffteducationdatalab.org.uk/a-level/english-language.php? $\mathrm{v}=20190815>$ (Accessed November 3, 2019).

Giovanelli, M. 2015. 'Becoming an English language teacher: Linguistic knowledge, anxieties and the shifting sense of identity.' Language and Education, 29(5), 416-429.

Helm, T. 2019. “"Easier” exams offered by private schools smooth pupils' entry to top universities: Russell Group members admit they treat less-rigorous IGCSEs the same as new, harder GCSEs'. The Guardian, August 24. Online at: <https://www.theguardian.com/education/2019/aug/ 24/private-schools-igcse-exams-easier-gcse-universityadmissions $>$ (Accessed November 3, 2019).

Hudson, R. 2019. 'Historical background to A-level English Language' [PPT presentation]. 'LAGB Education Committee: The drop in uptake of English Language A level' [Panel Discussion]. September 11, Queen Mary University London. Online at: $<$ https://lagb-education.org/ lagb-education-sessions $>$ (Accessed November 3, 2019).

Hughes, H. 2019. 'A-level English is under threat. Can we save it? Entries for A-level English have dropped sharply. What's is putting students off? And how can we tempt them back?' Times Educational Supplement, July 31. Online at: $<$ https://www.tes.com/news/a-level-englishdying-can-we-save-it> (Accessed November 3, 2019).

Humphrys, J. 2006. Lost for Words: The Mangling and Manipulating of the English Language. London, UK: Hodder \& Stoughton.

Kennedy, M. 2014. 'To Kill a Mockingbird and Of Mice and Men axed as Gove orders more Brit Lit.' The Guardian, May 25. Online at: $<$ https://www.theguardian.com/ education/2014/may/25/mockingbird-mice-and-menaxed-michael-gove-gcse > (Accessed November 3, 2019).

Kingman, J. et al. 1988. The Kingman Report. Report of the Committee of Inquiry into the Teaching of English Language. London, UK: HM Stationery Office. Online at: $<$ http://www.educationengland.org.uk/documents/ kingman/> (Accessed November 3, 2019).

Kroskrity, P. V. 2004. 'Language ideologies.' In A. Duranti (ed.), A Companion to Linguistic Anthropology. Oxford, UK: Blackwell Publishing Ltd, pp. 496-517.

Leedham, D. 2019. 'Subject English/es at A Level: Possible barriers and enablers provided via the current GCSE specification' [PPT presentation]. 'LAGB Education Committee: The drop in uptake of English Language A level' [Panel Discussion]. September 11, Queen Mary University London. Online at: $<$ https://lagb-education.org/ lagb-education-sessions $>$ (Accessed November 3, 2019).

Lough, C. 2019. 'New English GCSE texts "reinforce stereotypes." English teachers say additional "diverse" texts for English literature GCSE risk "othering” BAME communities.' Times Educational Supplement, August, 25. Online at: $<$ https://www.tes.com/news/new-englishgcse-texts-reinforce-stereotypes $>$ (Accessed November, 2019).

Mathieson, M. 1975. The Preachers of Culture. A Study of English and Its Teachers. London, UK: George Allen \& Unwin Ltd.

Myhill, D. 2016. 'The effectiveness of explicit language teaching: Evidence from the research.' In M. Giovanelli \& D. Clayton (eds.), Linguistics and the Secondary English 
Classroom. London, UK \& New York, USA: Routledge, pp. 36-49.

Newbolt, H. et al. 1921. The Teaching of English in England. Report of the Departmental Committee Appointed by the President of the Board of Education to Inquire into the Position of English in the Educational System of England. London, UK: HM Stationery Office. Online at: <http:// www.educationengland.org.uk/documents/newbolt/ newbolt1921.html > (Accessed November 3, 2019).

Nutt, J. 2019. 'Why GCSE English Language needs a reboot.' Times Educational Supplement, January $5^{\text {th }}$. Online at: <https://www.tes.com/news/why-gcse-englishlanguage-needs-reboot $>$ (Accessed November 3, 2019).

Pearce, J. 1974. 'Examinations in English Language.' In S. Lushington (ed.), Schools Council Programme in Linguistics and English Teaching Papers Series II. Vol. 4. Language: Classroom and Examinations. London, UK: Longman Group Ltd, pp. 35-70.

Protherough, R. \& Atkinson, J. 1991. The Making of English Teachers. Buckingham, UK \& Bristol, PA, USA: Open University Press.

Tickle, L. 2013. 'Do Michael Gove's GCSE changes pose a threat to English literature in schools?' The Guardian, July 15. Online at: $<$ https://www.theguardian.com/education/ 2013/jul/15/michael-gove-gcse-changes-englishliterature $>$ (Accessed November 3, 2019).

Truss, L. 2003. Eats, Shoots and Leaves: The Zero Tolerance Approach to Punctuation. London: Profile Books.

Van Rijt, J. \& Coppen, P. -A. 2017. 'Bridging the gap between linguistic theory and L1 grammar education experts' views on essential linguistic concepts.' Language
Awareness, 26(4), 360-380. DOI: 10.1080/

09658416.2017 .1410552

Verhoeven, B. 2017. 'Mixed messages for teachers? A critical discourse analysis of official secondary english documentation using corpus linguistics methods' [Paper]. Post Graduate Conference in Linguistics. March 31, University of Newcastle. Newcastle-upon-Tyne, UK. Online at: $<$ https://www.academia.edu/32515474/Mixed Messages_for_Teachers_A_Critical_Discourse_ Analysis_of_Official_Secondary_English Documentation_Using_Corpus_Linguistics_Methods> (Accessed November 3, 2019). DOI: 10.13140/ RG.2.2.13939.32808

Verhoeven, B. 2019. 'Equally prescriptivist and descriptivist: English teachers and contemporary (English) language ideologies' [Presentation]. Post-Graduate Conference in Linguistics. June 26, University of Huddersfield. Huddersfield, UK. Online at: $<$ https://www. academia.edu/32515474/Mixed_Messages_for Teachers_A_Critical_Discourse_Analysis_of_Official Secondary_English_Documentation_Using_Corpus Linguistics_Methods $>$ (Accessed November 3, 2019). DOI: $10.13140 /$ RG.2.2.36443.62242

Watson, A. 2012. 'Navigating "the pit of doom": Affective responses to teaching "grammar".' English in Education, 46(1), 22-38. DOI: 10.1111/j.1754-8845.2011.01113.x

Whittaker, F. 2019. 'Replace GCSE English language with “passport to English”, says ASCL commission.' Schools Week, September 11. Online at: <https://schoolsweek.co. uk/ascl-forgotten-third-commission-gcse-englishlanguage-passport/> (Accessed November 3, 2019). 